\title{
Musculoskeletal disorders, stress perception and physical activity in police officers
}

\author{
Desordens musculoesqueléticas, percepção de estresse e atividade física em policiais \\ Trastornos musculoesqueléticos, percepción del estrés y actividad física en agentes de policía \\ Maysa Venturoso Gongora Buckeridge Serra', João Domingos Scalon², Maria Georgina Marques Tonello3, \\ Paulo Roberto Veiga Quemelo ${ }^{4}$
}

\begin{abstract}
I The purpose of this study is to analyze association between stress perception and physical activity with the prevalence of symptoms of musculoskeletal disorders (SMSD) in police officers. The police officers ( $n=142$ ) answered the Perceived Stress Scale-10 (PSS-10) and the Nordic Musculoskeletal Questionnaire. Pearson's linear correlation coefficient was used to measure strength and direction of relationship between PSS-10 and prevalence of SMSD and showed a positive correlation between variables in the last 7 days ( $r=0.34, p=0.00001)$ and in the last 12 months ( $r=0.40$, $p=0.00001)$. The mean prevalence of SMSD in the last 12 months was lower among police officers practicing physical activity ( $W=1888.5, p=0.04$ ). Multiple logistic regression analysis showed that the practice of physical activities as well as efforts to reduce stress perception both decrease the odds of musculoskeletal disorders. This study indicated that stress level and physical activity practice influenced in prevalence of SMSD. Multidisciplinary interventions with actions to reduce stress level and encourage physical activity practice are needed to control SMSD prevalence.

Keywords I Police; Occupational Risks; Motor Activity; Stress Psychological; Musculoskeletal System.
\end{abstract}

RESUMO I O objetivo deste estudo foi analisar a associação entre percepção de estresse e atividade física com a prevalência de sintomas de distúrbios musculoesqueléticos (SDM) em policiais. Os policiais $(n=142)$ responderam à escala de estresse percebido-10 (EEP-10) e ao questionário nórdico-musculoesquelético. O coeficiente de correlação linear de Pearson foi utilizado para mensurar a força e o sentido da relação existente entre EEP-10 e a prevalência de SDM e mostrou que existe uma correlação positiva entre as variáveis nos últimos 7 dias $(r=0,34, p=0,00001)$ e nos últimos 12 meses ( $r=0,40, p=0,00001)$. A prevalência média de SDM nos últimos 12 meses é menor entre os policiais que praticam atividade física ( $W=1888,5, p=0,04)$. A análise de regressão logística múltipla mostrou que a prática de atividades físicas e a diminuição na percepção do estresse reduzem a prevalência de SDM. Este estudo indicou que o nível de estresse e a prática de atividade física influenciaram a prevalência de SDM. Intervenções multidisciplinares com ações para reduzir o nível de estresse e encorajar a prática de atividade física são necessárias para controlar a prevalência de SDM.

Descritores I Polícia; Riscos Ocupacionais; Atividade Física; Estresse Psicológico; Sistema Musculoesquelético.

RESUMEN I El objetivo de este estudio fue analizar la asociación entre estrés percibido y actividad física con prevalencia de síntomas del trastorno musculoesquelético (STM) en los agentes de policía. Los oficiales de policía ( $n=142)$ respondieron la escala de estrés percibido-10 (EEP-10) y el Cuestionario nórdico-musculoesquelético. Coeficiente de correlación lineal de Pearson se utilizó para medir fuerza y dirección entre EEP-10 y prevalencia de STM y mostró que hubo una correlación positiva entre las variables últimos 7 días ( $r=0,34, p=0,00001)$ y últimos 12 meses ( $r=0,40$, $p=0,00001)$. La prevalencia promedio de STM en últimos 12 meses es menor entre los oficiales que realizan actividad física ( $W=1888,5, p=0,04)$. El análisis de regresión logística

This study was conducted in University of Franca (Unifran) - Franca (SP), Brazil.

'Universidade de Franca (Unifran) - Franca (SP), Brazil. E-mail: ma_buckeridge@hotmail.com. Orcid: 0000-0002-3576-5009

2Universidade Federal de Lavras (UFLA) - Lavras (MG), Brazil. E-mail: scalon@ufla.br. Orcid: 0000-0001-8884-1442

3 Universidade de Franca (Unifran) - Franca (SP), Brazil. E-mail: gina@ginatonello.com.br. Orcid: 0000-0002-8129-2177

${ }^{4}$ Centro Universitário São Camilo - São Paulo (SP), Brazil. E-mail: pquemelo@hotmail.com. Orcid: 0000-0003-4245-0205 
múltiple mostró que actividad física y disminución de percepción del estrés reducen prevalencia de STM. El presente estudio indicó que nivel de estrés y actividad física influyó en prevalencia de STM. Las intervenciones multidisciplinarias con acciones para reducir los niveles de estrés y fomentar la actividad física son necesarias para controlar la prevalencia de STM.

Palabras clave I Policía; Riesgos Laborales; Actividad Motora; Estrés Psicológico; Sistema Musculoesquelético.

\section{INTRODUCTION}

Police officers often perform activities associated with stress-causing factors, such as ostensible surveillance work and preservation of public order ${ }^{1-3}$. Excessive exposure to risks and violence, corporative efficiency charges and poor working conditions all contribute to make police officers most susceptible to stress ${ }^{4,5}$. Work stress costs are high and can be reflected both in mental health (frustration, anxiety and depression) and in physical health including the prevalence of symptoms of musculoskeletal disorders (SMSD) ${ }^{6}$.

Stress may be associated with an increase in $\mathrm{SMSD}^{7}$. Studies have shown that police officers have a higher prevalence of SMSD complaints in the following areas of the body: lower back, back, neck and knee ${ }^{6-8}$. Prevalence of these symptoms is directly related to these professionals' work specifics, such as running, jumping, and shooting, which consequently may cause physical trauma, the main reason for orthopedic problems ${ }^{3}$.

There is evidence for effectiveness of physical activity in significantly reducing SMSD prevalence among office workers 9 . The association analysis between stress level, physical activity practice and SMSD can provide important information in developing public strategies for policework. Thus, the aim of this study was to investigate association of SMSD prevalence with stress perception and physical activity among police officers.

\section{METHODOLOGY}

This is a cross-sectional study conducted with the Brazilian Military Police. The subjects to this study were 142 male police officers. Through a brief initial questionnaire, sociodemographic variables were collected, including age, height, weight, body mass index (BMI), marital status and number of children, as well as occupational variables such as working time in the corporation, working time in current function, working hours, if they had been away from work in the last 12 months and if they performed some type of physical exercise more than three times a week. BMI — the ratio of mass $(\mathrm{kg})$ and height $\left(\mathrm{m}^{2}\right)$ — was calculated from values reported by police officers. BMI values were classified as $<18.5 \mathrm{~kg} / \mathrm{m}^{2}$ (underweight); $18.5 \mathrm{~kg}$ to $24.9 \mathrm{~kg} / \mathrm{m}^{2}$ (normal); $25 \mathrm{~kg}$ to $29.9 \mathrm{~kg} / \mathrm{m}^{2}$ (overweight); and $>30 \mathrm{~kg} / \mathrm{m}^{2}$ (obese) ${ }^{10}$. Police officers developing their functions in Radio Patrol Standard with a shift of $12 \times 24$ (12 hours working, followed by 24 hours of rest) and $12 \times 48$ (12 hours working, followed by 48 hours of rest).

The inclusion criteria were police officers with more than a year of activity in the military police operational sector, that accepted answering the questionnaires and that filled out the informed consent form. Exclusion criteria consisted of police officers away from their activities and who did not attend during the day of the data collection.

To analyze perceived stress, the Perceived Stress Scale-10 (PSS-10) was used, proposed by Cohen, Kamarck and Mermelstein ${ }^{11}$ and validated in Brazil by Reis, Hino and Añez ${ }^{12}$. This instrument, based on officer self-reporting, intends to achieve global measure of stress in order to assess what situation in the individual's life is perceived as stressful. The results of stress level can range from 0 to 40 , correlating a higher score with a higher perceived stress level ${ }^{11}$.

To evaluate SMSD prevalence, the general content of the Nordic Musculoskeletal Questionnaire developed by Kuorinka et al. ${ }^{13}$ was used, adapted and validated to Portuguese by Barros and Alexandre ${ }^{14}$. The Nordic questionnaire objectively standardizes analysis to SMSD prevalence and allows data comparison from different studies.

An exploratory analysis of the variables was performed, using graphics, equations, percentages, means and standard deviations. Pearson's linear correlation coefficient was used to measure the strength and direction of the relationship between PSS-10 and the SMSD prevalence. The ShapiroWilks test was used to check data for normal distribution. Student's t-test was used to compare the means of two groups under the assumption that both samples were random, independent, and originated from normally distributed population, while the Mann-Whitney w-test was used to test the null hypothesis that two independent samples came from the same population with non-normal 
distribution. We used a multiple logistic regression model to calculate probabilities and odds ratios for SMSD prevalence. The statistical methods used in this work are described by Peat and Barton ${ }^{15}$. Data were analyzed using $\mathrm{R}$ software R Core team ${ }^{16}$.

\section{RESULTS}

Most of the workers were married (65\%), practiced regular physical activity $(62 \%)$ with time in company of 149.85 months $( \pm 78.35)$ (Table 1$)$.

Table 1. Sample mean ( \pm standard deviation) of the quantitative variables

$\begin{array}{lr}\text { Variables } & \text { Mean }( \pm \text { sd }) \\ \text { Age (years) } & 36.44( \pm 6.31) \\ \text { Number of children } & 1.49( \pm 1.16) \\ \text { Time in company (months) } & 149.85( \pm 78.35) \\ \text { Time in current job (months) } & 127.73( \pm 81.63) \\ \text { Height (meters) } & 1.77( \pm 0.06) \\ \text { Weight }(\mathrm{kg}) & 86.67( \pm 12.48) \\ \left.\text { BMl (kg/height }{ }^{2}\right) & 27.64( \pm 3.39) \\ \text { Variables } & \text { Absolute }(\%) \text { values } \\ \text { PA } 3 \times \text { Week } & 88(62 \%) \\ \text { Single } & 38(27 \%) \\ \text { Married } & 92(65 \%) \\ \text { Divorced } & 12(8 \%)\end{array}$

BMI: body mass index; PA: physical activity.

Regarding SMSD prevalence in the last twelve months, police officers reported feeling more pain in the lower back (47\%) and dorsal region (33\%), as shown in Table 2.

Table 2. Absolute values and percentages of the number of police officers with musculoskeletal symptoms in the last 12 months

\begin{tabular}{lc}
\multicolumn{1}{c}{ SMSD } & Absolute (\%) values \\
Lower back & $67(47 \%)$ \\
Dorsal region & $47(33 \%)$ \\
Hip-Thigh & $45(32 \%)$ \\
Knees & $45(32 \%)$ \\
Ankles & $40(28 \%)$ \\
Neck & $36(25 \%)$ \\
Shoulder & $36(25 \%)$ \\
Fists-Hands-Fingers & $35(24 \%)$ \\
Forearm & $16(11 \%)$ \\
Elbow & $12(8 \%)$
\end{tabular}

SMSD: musculoskeletal symptoms.
The linear correlation coefficient between stress level with SMSD in the last seven days was statistically significant $(r=0.34, p=0.00001)$, and the correlation coefficient between stress level and SMSD in last 12 months was, also, statistically significant $(\mathrm{r}=0.40, \mathrm{p}=0.00001)$. This, therefore, indicates a moderate positive linear correlation between two variables at the two situations.

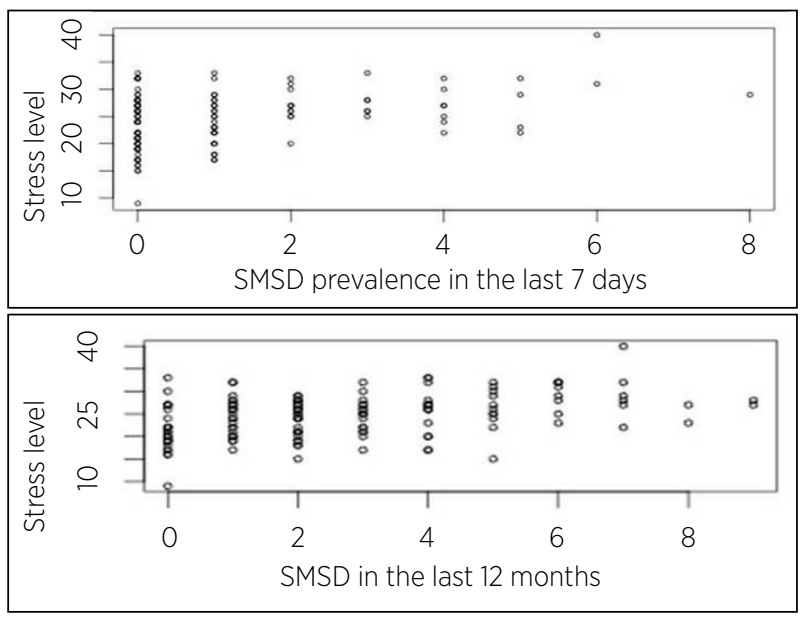

Figure 1. Scatter plot of stress level with SMSD prevalence in the last 7 days and 12 months

All police officers, who have and have not practiced physical activity more than three times/week, were included. SMSD: musculoskeletal symptoms.

Mean stress level tended to be lower among police officers who practiced physical activity more than three times/week (mean=24.01) than among police officers who did not (mean=25.33). However, there were no statistically significant differences $(t=-1.69, \mathrm{p}=0.09)$. Similarly, the mean prevalence of SMSD in last 12 months is lower among police officers who practiced physical activity more than three times/week than among police officers who did not (mean $=2.40$ vs $3.09, \mathrm{w}=1888.5, \mathrm{p}=0.04$ ) as shown in Figure 2.

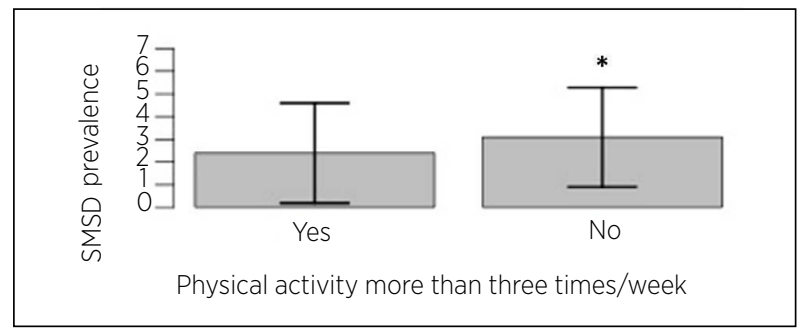

Figure 2. The sample mean of SMSD prevalence among police officers who have and have not practiced physical activity more than three times/week

Error bars represent standard deviation. SMSD: symptoms of musculoskeletal disorders

The log odds of the prevalence of SMSD in the last 12 months were estimated by the logit model 
$\ln (o d d s)=\ln (p /(1-p))=-2.67+0.19 \times$ stress_leve $0.35 \times$ physical_activity. It shows that practicing physical activities in the last 12 months reduces the odds of getting musculoskeletal symptoms by $30 \%$, while a unit increase in stress perception increases the odds by $21 \%$.

The model also shows that a police officer with a maximum stress level (PSS-10=40) who did not practice physical activities in the last 12 months presents a probability of 0.82 of developing some type of musculoskeletal disorder. On the other hand, a police officer without stress (PSS-10=0) who has practiced physical activities in the last 12 months has a very low probability (equal to 0.04 ) to develop some type of musculoskeletal symptom.

\section{DISCUSSION}

This study has shown that stress is directly associated with SMSD prevalence in the last seven days and SMSD prevalence in the last 12 months. Police officers are among the professionals most vulnerable to accidents and deaths in exercise of their work and most exposed to danger and aggression, often involved in everyday conflict situations generating tension, SMSD prevalence and occupational stress ${ }^{17-19}$.

Occupational stress is an imbalance perceived between work demands and the worker's ability to cope, with differences between each person's ideal working routine and the reality of their working conditions being the only reason to report stress perceived at work ${ }^{20,21}$. Occupational stress is considered a risk factor in triggering metabolism changes, and stress can appear through minor psychological trauma that police officers might face ${ }^{22,23}$.

Studies worldwide claim that the effects of occupational stress may result in anxiety, depression, alcoholism, insomnia, increased aggression, suicidal attempts or ideation, obesity, gastrointestinal diseases, hypertension, coronary heart disease, as well as other conditions ${ }^{24,25}$. In this context, strategies such as the practice of physical activity are important to be considered, as they deal with stress risks and improve both quality of work and personal life, avoiding consequences to occupational stress for these professionals. It is important to highlight that stress is the cause of several health problems, such as SMSD prevalence, and that the most common and unavoidable stressors are those connected with work ${ }^{26}$.

Some studies shown SMSD prevalence related to occupational stress ${ }^{26-28}$. The SMSD risk factors are known to be generated by work activities, such as carrying of work equipment (ballistic vest, gun, ammunition, among others), repetitive tasks and incorrect posture, generating SMSD prevalence in specific body parts such as the lumbar spine, which corroborates this study's findings ${ }^{29}$. Economic losses due to SMSD prevalence affect not only the individual but also the corporation and society, since SMSD can lead to inability and absenteeism ${ }^{30}$, contributing to the relevancy of this study.

In this study, the police officers that practiced physical activity reported less occupational stress than participants that did not. Physical activity can decrease stress because people who practice it display lower cortisol levels, better heart rate response, more calmness and less frequent anxiety states than people who do not practice it, suggesting that physical activity may produce a protective effect against diseases related to occupational stress ${ }^{31-33}$.

Police officers may be required to use force in search of a suspect, showing physical fitness is essential to this population $^{34}$. This study demonstrated police officers who exercise more than three times a week had fewer SMSD prevalence in the last seven days and in the last 12 months. One possible explanation for these findings may be due to the protective factor that physical exercise causes in the body, bringing better joint stability, flexibility and muscular endurance ${ }^{35,36}$. In this sense, regular physical exercise practice is an important factor for police officers to avoid stress, SMSD prevalence and reduce absenteeism ${ }^{37,38}$.

In conclusion, there was significant association between stress and SMSD prevalence. The prevalence of SMSD is lower among police officers who practice physical activity. This study indicated that stress level and physical activity influenced positive or negative in SMSD prevalence. Therefore, multidisciplinary intervention which includes actions to reduce stress level and encourage physical activity practice are needed to control SMSD prevalence in police officers.

\section{REFERENCES}

1. Chang JH, Huang PT, Lin YK, Lin CE, Lin CM, Shieh YH, Lin YC. Association between sleep duration and sleep quality, and metabolic syndrome in taiwanese police officers. Int J Occup Med Environ Health. 2015;28(6):1011-23. doi: 10.13075/ijomeh.1896.00359

2. Garbarino S, Cuomo G, Chiorri C, Magnavita N. Association of work-related stress with mental health problems in a special police force unit. BMJ Open. 2013;3(7):e002791. doi: 10.1136/ bmjopen-2013-002791 
3. Minayo MCS, Assis SG, Oliveira RVC. The impact of professional activities on the physical and mental health of the civil and military police of Rio de Janeiro (RJ, Brazil). Cienc Saude Coletiva. 2011;16(4):2199-209. doi: 10.1590/ S1413-81232011000400019

4. Shiozaki M, Miyai N, Morioka I, Utsumi M, Hattori S, Koike H, et al. Job stress and behavioral characteristics in relation to coronary heart disease risk among japonese police officers. Ind Health. 2017;55(4):369-80. doi: 10.2486/indhealth.2016-0179

5. Souza ER, Franco LG, Meireles CC, Ferreira VT, Santos NC. Psychological distress among civilian police: a gender-based analysis. Cad Saude Publica. 2007;23(1):105-14. doi: 10.1590/ S0102-311X2007000100012

6. Hoy D, March L, Brooks P, Blyth F, Woolf A, Bain C, et al. The global burden of low back pain: estimates from the Global Burden of Disease 2010 study. Ann Rheum Dis. 2014;73(6):968-74. doi: 10.1136/annrheumdis-2013-204428

7. Vieira ER, Serra MVGB, Almeida LB, Villela WV, Scalon JD, Quemelo PRV. Symptoms and risks for musculoskeletal disorders among male and female footwear industry workers. Int J Ind Ergon. 2015;48:110-6. doi: 10.1016/j.ergon.2015.05.001

8. Trindade APNT, Oliveira LCN, Santos BMO, Oliveira FB, Quemelo PRV. Symptoms of musculoskeletal disorders among police officers. Arq Ciênc Saude. 2015;22(2):42-5. doi: 10.17696/2318-3691.22.2.2015.141

9. Andersen LN, Juul-Kristensen B, Roessler KK, Herborg LG, Sørensen TL, Søgaard K. Efficacy of 'Tailored Physical Activity' in reducing sickness absence among health care workers: design of a randomised controlled trial. Man Ther. 2015;20(5):666-71. doi: 10.1016/j.math.2015.04.017

10. Oreopoulos A, Padwal R, Kalantar-Zadeh K, Fonarow C, Norris CM, McAlister FA. Body mass index and mortality in heart failure: a meta-analysis. Am Heart J. 2008;156(1):13-22. doi: 10.1016/j.ahj.2008.02.014

11. Cohen S, Kamarck T, Mermelstein RA. A global measure of perceived stress. J Health Soc Behav. 1983;24(4):385-96. doi: 10.2307/2136404

12. Reis RS, Hino AA, Añez CR. Perceived stress scale: reliability and validity study in Brazil. J Health Psychol. 2010;15(1):107-14. doi: 10.1177/1359105309346343

13. Kuorinka I, Jonsson B, Kilbom A, Vinterberg H, BieringSørensen F, Andersson G, Jørgensen K. Standardised Nordic questionnaires for the analysis of musculoskeletal symptoms. Appl Ergon. 1987;18(3):233-7. doi: 10.1016/0003-6870(87)90010-x

14. Barros ENC, Alexandre NMC. Cross-Cultural Adaptation of the Nordic Musculoskeletal Questionnaire. Int Nurs Rev. 2003;50(2):101-8. doi: 10.1046/j.1466-7657.2003.00188.x

15. Peat J, Barton B. Medical Statistics: a Guide to Data Analysis and Critical appraisal. Malden: Blackwell, 2015.

16. R Foundation. R: a language and environment for statistical computing, 3. Vienna: R Foundation for Statistical Computing; 2019.

17. Fanavoll R, Nilsen TI, Holtermann A, Mork PJ. Psychosocial work stress, leisure time physical exercise and the risk of chronic pain in the neck/shoulders: Iongitudinal data from the norwegian HUNT study. Int J Occup Med Environ Health. 2016;29(4):585-95. doi: 10.13075/ijomeh.1896.00606
18. Santos MMA, Souza EL, Barroso BIL. Analysis of the perception of state police officers regarding the comfort of bulletproof vests. Fisioter Pesqu. 2017;24(2),157-62. doi: 10.1590/1809-2950/16629324022017

19. Souza LAS, Torres ARR, Barbosa GA, Lima TJS, Souza LEC. Selfefficacy as a mediator of the relationship between subjective well-being and general health of military cadets. Cad Saude Publica. 2014;30(11):2309-19. doi: 10.1590/0102-311X00177513

20. Arial M, Gonik V, Wild P, Danuser B. Association of work related chronic stressors and psychiatric symptoms in a Swiss sample of police officers; a cross sectional questionnaire study. Int Arch Occup Environ Health. 2010;83(3):323-31. doi: 10.1007/ s00420-009-0500-z

21. Lipp MEN. Stress and quality of life of senior Brazilian Police Officers. Rev Bras Ter Cogn. 2016;12(2):100-4. doi: 10.5935/1808-5687.20160016

22. Juniper B, White N, Bellamy P. A new approach to evaluating the well-being of police. Occup Med (Lond.). 2010;60(7):560-5. doi: 10.1093/occmed/kqq130

23. Magnavita N, Fileni A. Work stress and metabolic syndrome in radiologists: first evidence. Radiol Med. 2014;119(2):142-8. doi: 10.1007/s11547-013-0329-0

24. Jacobs M, Pienaar J. Stress, coping and safety compliance in a multinational gold mining company. Int J Occup Saf Ergon. 2017;23(2):152-61. doi: 10.1080/10803548.2016.1263476

25. Nelson KV, Smith AP. Occupational stress, coping and mental health in Jamaican police officers. Occup Med (Lond.). 2016;66(6):488-91. doi: 10.1093/occmed/kqw055

26. Dawson AP, Schluter PJ, Hodges PW, Steward S, Turner C. Fear of movement, passive coping, manual handling, and severe or radiating pain increase the likelihood of sick leave due to low back pain. Pain. 2011;152(7):1517-24. doi: 10.1016/j.pain.2011.02.041

27. Haukka E, Leino-Arjas P, Ojajarvi A, Takala EP, Viikari-Juntura E, Riihimäki H. Mental stress and psychosocial factors at work in relation to multiple-site musculoskeletal pain: a longitudinal study of kitchen workers. Eur J Pain. 2011;15(4):432-8. doi: 10.1016/j. ejpain.2010.09.005

28. Westgaard RH, Winkel J. Occupational musculoskeletal and mental health: significance of rationalization and opportunities to create sustainable production systems a systematic review. Appl Ergon. 2011:42(2):261-96. doi: 10.1016/j.apergo.2010.07.002

29. Souza CS, Oliveira AS. Referrals Prevalence of the musculoskeletal diseases according to the international statistical classification of diseases (ICD-10): reflections for education in musculoskeletal physiotherapy. Fisioter Pesqui. 2015;22(1):48-53. doi: 10.590/1809-2950/13158722012015

30. Thetkathuek A, Meepradit P. Work-related musculoskeletal disorders among workers in an MDF furniture factory in eastern Thailand. Int J Occup Saf Ergon. 2018;24(2):207-17. doi: 10.1080/10803548.2016.1257765

31. Serra MVGB, Camargo PR, Zaia JE, Tonello MGM, Quemelo PRV. Effects of physical exercise on musculoskeletal disorders, stress and quality of life in workers. Int J Occup Saf Ergon. 2018;24(1):62-7. doi: 10.1080/10803548.2016.1234132

32. Kettunen O, Vuorimaa T, Vasankari T. A 12-month exercise intervention decreased stress symptoms and increased mental resources among working adults - results perceived 
after a 12-month follow up. Int J Occup Med Environ Health. 2015;28(1):157-68. doi: 10.13075/ijomeh.1896.00263

33. Rimmele U, Zellweger BC, Marti B, Seiler R, Mohiyeddini C, Ehlert U, Heinrichs M. Trained men show lower cortisol, heart rate and psychological responses to psychosocial stress compared with untrained men. Psychoneuroendocrinology. 2007;32(6):627-35. doi: 10.1016/j.psyneuen.2007.04.005

34. Bissett D, Bissett J, Snell C. Physical agility tests and fitness standards: perceptions of law enforcement officers. Police Pract Res. 2012;13(3):208-23. doi: 10.1080/15614263.2011.616142

35. Cardoso M, Girouard M, Callaghan JP, Albert WJ. An ergonomic evaluation of city police officers: an analysis of perceived discomfort within patrol duties. Int J Occup Saf Ergon. 2017;23(2):175-84. doi: 10.1080/10803548.2016.1249728
36. Ciolac EG, Rodrigues-da-Silva JM. Resistance training as a tool for preventing and treating musculoskeletal disorders. Sports Med. 2016;46(9):1239-48. doi: 10.1007/ s40279-016-0507-z

37. Klussmann A, Gebhardt H, Liebers F, Rieger MA. Musculoskeletal symptoms of the upper extremities and the neck: a cross-sectional study on prevalence and symptom-predicting factors at visual display terminal (VDT) workstations. BMC Musculoskelet Disord. 2008;9:96. doi: 10.1186/1471-2474-9-96

38. Motamedzade M, Mohseni M, Golmohammadi R, Mahjoob $H$. Ergonomics intervention in an Iranian television manufacturing industry. Work. 2011;38(3):257-63. doi: 10.3233/WOR-2011-1129 